\title{
The Role of Art Design Teachers in Classroom Teaching
}

\author{
Cancan Guo \\ Department of Art Design, Ginkgo Hotel Management College \\ Chengdu Information Engineering University, \\ Chengdu, Sichuan province, P.R.C \\ Cancan2001@163.com
}

\begin{abstract}
In order to develop professional knowledge on art design and improve the practicality of classroom teaching and classroom management, professional teacher organization courses are proposed for classroom teaching in this study. The methods to improve the quality of teaching in classroom teaching were discussed. As was shown in the result, the professional knowledge that is reflected in classroom teaching helps students develop their skills, improves classroom management, and allows teachers to provide effective counseling.
\end{abstract}

Keywords-art design, professional teachers, classroom teaching

\section{INTRODUCTION}

Art design is an important part of institutions of higher learning specializing in this field. Art design teachers primarily teach in classrooms, and in such an environment, teaching should vigorously promote the participation of students. In addition, teachers must focus on the subjective initiative of teaching. Therefore, teachers should provide students with a positive learning atmosphere.

\section{THE ROLE OF ORgANIZATION IN CLASSROOM TEACHING}

Art and design teachers play important organizational roles in and out of a classroom [1-3]. Preparation is a prerequisite for effective lessons, and teachers should be fully prepared before coming to class to achieve good results in teaching. Professional teachers should have a wealth of professional knowledge in new designs and teaching practices as well as a thorough understanding of teaching methods. Moreover, they should focus on discipline and direction and constantly enrich and update teaching content and methods to improve the quality of teaching and the effectiveness of teaching art design[4-6].

Effective teaching focuses on the use of teaching materials, practice of teaching processes using various media, the use of appropriate and updated teaching content, processing, writing to determine a student's cognitive level of teaching programs, carrying out of network preparation, teaching organization, and the use of multimedia platforms[7-8].

Aside from organizing lessons in class; planning student learning, classroom practice, group discussions, and other organizational considerations in classrooms; as well as possessing good teaching skills, professional teachers must be open, interactive, and innovative. Moreover, they should be able to understand the close relationship between design creation and social economy. Other tasks include organizing students for practice learning and establishing contact with companies or institutions to enable students to practice what they have learned and apply theoretical knowledge in learning. To perform these tasks, specific and detailed tasks should be completed by professional teachers before conducting classes. Students must also be trained to discover new ideas, expand their knowledge, and use what they have learned [9-10].

\section{The Role of Professional KNOWLEDGE TRANSFER IN CLASSROOM TEACHING}

Design style materials evolve dynamically; thus, theory and practice must be closely integrated by professionals. Teachers must read design books to gather visual aids and determine excellent design work for students, thus enabling them to understand current design styles, philosophies, and the current state of the market, providing them a sound theoretical foundation. Lectures should also integrate theories to establish specific program designs and construction management strategies [11-16].

Teachers must effectively employ multimedia-assisted teaching. Multimedia teaching differs from the traditional concept of teaching. Illustrated courseware can improve students' aesthetic ability and taste, which in turn, encourage their participation and stimulate their interest in learning. For example, the multimedia courseware in the "Garden Design" course shows students some representative work on Western landscape design. The representative works of the Chinese garden of Suzhou, which include the Lingering Garden, Zhuozhengyuan, and Lion Grove, can also be highlighted to explain the basic structure of Chinese gardens. In this way, students can gain a preliminary understanding of landscape design and knowledge as well as new garden designs in the Chinese context. Indeed, multimedia-aided teaching increases teaching capacity and improves the quality and effect of teaching, while helping students learn more about distinct Eastern and Western garden styles and characteristics.

Teachers impart professional knowledge and help students develop their communication skills with customers. Hence, customers can understand and recognize their own design ideas. Therefore, at the end of each design course, students must be able to communicate their own designs, ideas, and concepts. 
Teachers must also help students in drafting proposals. Finally, teachers and students must collaborate to find solutions to problems. Thus, students can improve their own design concepts and have avenues through which they can showcase themselves. Students apply their language skills, demonstrate their design skills, and become enthusiastic about learning[17].

\section{The Role of GUIDING STUdents In CLASSROOM TEACHING}

In professional classroom teaching, teachers should adopt helpful and flexible teaching methods, because various counseling methods apply to different students[18-19]. When students encounter problems in design, teachers should be guided by information to explore the problems, help students think properly, and guide students to discover, analyze, and solve design problems. Thus, students must maintain dynamic and active thinking, actively explore the lessons, learn creatively, and think innovatively.

Teachers should consciously guide students to teach them basic design methods and instill new design concepts, thus offering design ideas and laying the foundation for improved designs. Given that the professional knowledge of students is limited in the early stage of any design course, the maturity of their design ideas is insufficient. Teachers must guide students during the design process and help improve their ability to innovate[20]. For example, in the "Residential Space Design" course, students are allowed to form groups in building inspection units and writing study reports. Each group is asked to study two to three buildings and discuss the designs of these structures so that they can understand the basic methods of identifying unit types and determining ways to address the socalled "irrational structures."

An interactive teaching atmosphere deepens students' understanding of the basic knowledge of design and expands their thinking in design. Students express their ideas, learn from one another other, and become inspired. During heated discussions, students become open to other design ideas, expand their ability to identify various design methods, and improve their knowledge of multiple design concepts. The potential of design students is unlimited; thus, teachers should consciously train and guide them to tap their full potential.

\section{ClassRoom Teaching in the Management Role}

Classes are a basic unit in university management, and teachers and instructors are involved in direct and indirect management. The level of classroom management practiced by professional teachers directly determines the effect of classroom teaching. If the classroom environment is not conducive to learning, teaching cannot be effective. Therefore, the role of teachers in classroom management is crucial. In China, a student's growth and development are influenced by school culture and class subcultures. Teachers deal with individual students and are involved in the management and guidance of such students. Thus, the responsibility of teachers is substantial.

Teachers should have the knowledge and skills in education and teaching and must be able to master the basic class management methods[21-22]. They must be equipped with leadership skills and must be artistic, reasonable, and innovative in addressing problems in teaching. In preparation for the design profession, students must conduct field visits to different establishments, such as those with "decorative materials and budget.” Hence, students become knowledgeable in preparing a material budget and understanding commonly used materials, as well as their characteristics, uses, and prices. To help their students, teachers must also help students understand materials and prices, gain professional knowledge, and manage students effectively.

In this process, the influence of professional teachers and the role of class cadres cannot be disregarded. Class cadres must be mobilized to strengthen the safety of students in and out of the classroom.

\section{The Role of Practical Counseling in Classroom TEACHING}

With the advent of the economic era, the need to train practical and innovative personnel increases[23]. The teaching modes, methods, and contents must all be reformed, and practical teaching and application must be strengthened. To identify a suitable space for students to survive and develop in the employment market, classroom teaching must provide practical and training opportunities as well as avenues for students to develop their talents[24]. Possessing the abilities to cultivate talents who can adapt to society as well as develop and innovate is an important criterion in assessing the quality of teaching in learning institutions. In relation to this, the practice of theoretical knowledge must be strengthened to improve the quality of teaching. Skilled personnel are needed in society; thus, the training of students to acquire professional skills must be strengthened. With effective teaching, students can gain knowledge in practice, learn new ideas, and master their skills.

Furthermore, art and design teachers must have the flexibility to use basic knowledge and creativity to solve practical problems. For example, a teacher of a "furniture and furnishings" course can bring students to a furniture factory site so that students can study construction operations and the application of construction technology, enabling students to understand the application of theoretical knowledge in actual practice. Through such site visits, students can also become personally involved in analyzing illustrations, processes, and other specific practical operations[25-26]. As students become familiar with the learning process, their practical ability is improved and their knowledge becomes focused. Practical application can be closely integrated with professional teaching projects; in this way, students can learn actual construction processes and knowledge, improving their interest in the profession and enhancing their learning initiative and selfconfidence[27-28].

To conclude, the role of professional teachers in art design classes is crucial. Teachers should provide students with extensive learning materials and develop their abilities to cultivate design ideas, apply theoretical principles. 


\section{CONCLUSION}

Professional teacher organization courses are proposed for classroom teaching, in consideration of the rapidly developing professional knowledge on art design and the goal of improving the practicality of classroom teaching and classroom management. Professional knowledge that is reflected in classroom teaching helps students develop their skills, improves classroom management, and allows teachers to provide effective counseling. Methods to improve the quality of teaching in classroom teachings were discussed.

\section{ACKNOWLEDGMENT}

This work was financially supported by Agricultural Science and Technology Achievements Transformation Fund Project (2012GB2G000451) and Youth Scientific Research Projects in Henan Institute of Education (20100103).

\section{REFERENCES}

[1] Pavlou V. Understanding Art: Preparing Generalist School Teachers to Teach Art with Artworks[J]. International Journal of Art \& Design Education, 2015, 34(2): 192-205.

[2] Kuhn M A, Greenhalgh S, McDermott M. Using Creativity from Art and Engineering to Engage Students in Science[J]. Journal of STEM Arts, Crafts, and Constructions, 2016, 1(2): 2.

[3] Lai C L, Hwang G J. An interactive peer-assessment criteria development approach to improving students' art design performance using handheld devices[J]. Computers \& Education, 2015, 85: 149-159.

[4] McKenney S, Kali Y, Markauskaite L, et al. Teacher design knowledge for technology enhanced learning: an ecological framework for investigating assets and needs[J]. Instructional Science, 2015, 43(2): 181-202.

[5] Brown T, Wyatt J. Design thinking for social innovation[J]. Annual Review of Policy Design, 2015, 3(1): 1-10.

[6] McKenney S, Kali Y, Markauskaite L, et al. Teacher design knowledge for technology enhanced learning: an ecological framework for investigating assets and needs[J]. Instructional Science, 2015, 43(2): 181-202.

[7] Mangafa C, Moody L, Woodcock A, et al. The Design of Guidelines for Teachers and Parents in the Use of iPads to Support Children with Autism in the Development of Joint Attention Skills[C]//nternational Conference of Design, User Experience, and Usability. Springer International Publishing, 2016: 178-186.

[8] Janes K H. Planning art and design in the national curriculum[J]. Planning the Primary National Curriculum: A complete guide for trainees and teachers, 2015: 180.

[9] Chang H T, Lin T I. Discovering Taiwanese design college students' learning performance and imaginative capacity[J]. Thinking Skills and Creativity, 2013, 10: 23-39.

[10] Souleles N. The evolution of art and design pedagogies in England: Influences of the past, challenges for the future[J]. International Journal of Art \& Design Education, 2013, 32(2): 243-255.
[11] Mor Y, Craft B, Hernández-Leo D. Editorial: The art and science of learning design[J]. Research in Learning Technology, 2013, 21.

[12] Huizinga T, Handelzalts A, Nieveen N, et al. Teacher involvement in curriculum design: Need for support to enhance teachers' design expertise[J]. Journal of curriculum studies, 2014, 46(1): 33-57.

[13] Thorsteinsson G, Page T. Creativity in Design and Craft Education[C]//KODDCO 2014 Conference. 2014: 405-408.

[14] Gueudet G, Pepin B, Sabra H, et al. Collective design of an e-textbook: teachers' collective documentation[J]. Journal of Mathematics Teacher Education, 2016, 19(2-3): 187-203.

[15] Abdullah Z. Activity Theory as Analytical Tool: A Case Study of Developing Student Teachers' Creativity in Design[J]. Procedia-Social and Behavioral Sciences, 2014, 131: 70-84.

[16] Gonzalo J D, Heist B S, Duffy B L, et al. The art of bedside rounds: a multi-center qualitative study of strategies used by experienced bedside teachers[J]. Journal of general internal medicine, 2013, 28(3): 412-420.

[17] Blankman M, van der Schee J, Boogaard M, et al. Design and Development of a Geography Module for First-year Primary Student Teachers[J]. Curriculum and Teaching, 2016, 31(2): 5-25.

[18] Som İ, Türkan A, Altun S. Design of Introduction to Educational Sciences Course Using UbD: The Evaluation of Prospective Teachers' Achievment, Attitudes and Opinions About the Course[J]. International Journal of Social Sciences and Education Research, 2016, 2(4): 16591672.

[19] Morris J E, Lummis G W. Investigating the personal experiences and self-efficacy of Western Australian primary pre-service teachers in the visual arts[J]. Australian Art Education, 2014, 36(1): 26.

[20] Bell D. The reality of STEM education, design and technology teachers' perceptions: a phenomenographic study[J]. International Journal of Technology and Design Education, 2016, 26(1): 61-79.

[21] Van Dooren E, Boshuizen E, van Merriënboer J, et al. Making explicit in design education: generic elements in the design process[J]. International Journal of Technology and Design Education, 2014, 24(1): 53-71.

[22] Robson J. Engagement in structured social space: an investigation of teachers' online peer-to-peer interaction[J]. Learning, Media and Technology, 2016, 41(1): 119-139.

[23] Giffen Cheng Y H, Chou W S, Cheng C W. Research into Teachers' Receptivity for Arts Infused Curricula in Taiwan[J]. International Journal of Art \& Design Education, 2014, 33(1): 55-74.

[24] Brown N C M. Art education curriculum praxis: a time for collaboration[M]//Studies in Philosophical Realism in Art, Design and Education. Springer International Publishing, 2017: 79-93.

[25] Smith J E. Empowering Pasifika Students to Express their Identities through Visual Arts in New Zealand Secondary Schools: The Role of Euro-descendent Teachers[J]. International Journal of Multicultural Education, 2016, 18(2): 85-106.

[26] Reimann D, Maday C. Smart Textile objects and conductible ink as a context for arts based teaching and learning of computational thinking at primary school[C]//Proceedings of the Fourth International Conference on Technological Ecosystems for Enhancing Multiculturality. ACM, 2016: 31-35.

[27] Zimmerman A S. Developing Confidence in STEAM: Exploring the Challenges that Novice Elementary Teachers Face[J]. The STEAM Journal, 2016, 2(2): 15.

[28] Akinoglu O, Eren C D. Pre-service Teachers’ Metaphors Regarding the Concept of Scientific Thinking[J]. Anthropologist, 2015, 20(3): 476-484. 